\title{
Pemberdayaan Pemuda dalam Pengelolaan Limbah Kayu Bernilai Ekonomis di Desa Kemantren Kecamatan Jabung
}

\author{
${ }^{1}$ Febi Dwi Widayanti, ${ }^{2}$ Indria Kristiawan \\ ${ }^{1}$ Prodi Pendidikan Matematika, FKIP, Universitas Wisnuwardhana Malang, Jl. Danau Sentani \\ No. 99, Malang, Indonesia Mataram, Indonesia 65155 \\ ${ }^{2}$ Prodi Pendidikan Pancasila dan Kewarganegaraan, FKIP, Universitas Wisnuwardhana \\ Malang, Jl. Danau Sentani No. 99, Malang, Indonesia Mataram, Indonesia 65155
}

\section{Email Korespondensi:febidwi07@gmail.com}

\begin{tabular}{|c|c|}
\hline Arti & ract \\
\hline $\begin{array}{l}\text { Article History } \\
\text { Received: } 21-02-2020 \\
\text { Revised: } 29-02-2020 \\
\text { Published: } 02-03-2020\end{array}$ & \multirow{2}{*}{$\begin{array}{l}\text { Youth Empowerment in the Management of Economical Value Wood Waste } \\
\text { in Kemantren Village, Jabung District. The purpose of this activity is to } \\
\text { provide benefits and added value in the management of wood waste that can be } \\
\text { reprocessed and become simple works of art and have economic value. This } \\
\text { activity is intended for young people in the Kemantren Village, Jabung Sub- } \\
\text { District, Malang District. The implementation of this activity uses the cultural } \\
\text { approach method. The activities carried out are: socialization, assistance, and } \\
\text { monitoring. The results of this activity are having a positive impact on young } \\
\text { people who are equipped with knowledge and experience in utilizing wood } \\
\text { waste for the production of simple works of art that are economically valuable. } \\
\text { Artwork produced from wood waste in the form of wall hangings, photo frames, } \\
\text { stationery, bookshelves, door handles, and various wooden toys. This activity } \\
\text { can provide employment opportunities and opportunities for young people who } \\
\text { are skilled to increase their creativity }\end{array}$} \\
\hline $\begin{array}{c}\boldsymbol{K} \\
E \\
y \\
w \\
e c\end{array}$ & \\
\hline & \\
\hline $\begin{array}{l}\text { Sejar } \\
\text { Diter } \\
\text { Direv } \\
\text { Dipul }\end{array}$ & \multirow{2}{*}{$\begin{array}{l}\text { Tujuan kegiatan ini yaitu memberikan manfaat dan nilai tambah dalam } \\
\text { pengelolaan limbah kayu yang bisa diolah kembali dan menjadi karya seni } \\
\text { sederhana serta mempunyai nilai ekonomis. Kegiatan ini ditujukan untuk para } \\
\text { pemuda di Desa Kemantren Kecamatan Jabung Kabupaten Malang. } \\
\text { Pelaksanaan kegiatan ini menggunakan metode pendekatan kultural. } \\
\text { Pelaksanaan kegiatan yang dilakukan yaitu: sosialisasi, pendampingan, dan } \\
\text { monitoring. Hasil dari kegiatan ini yaitu memberikan dampak positif pada para } \\
\text { pemuda yang mendapatkan bekal pengetahuan dan pengalaman dalam } \\
\text { memanfaatkan limbah kayu untuk pembuatan karya seni sederhana yang } \\
\text { bernilai ekonomis. Karya seni yang dihasilkan dari limbah kayu berupa hiasan } \\
\text { dinding, frame foto, tempat ATK, rak buku, pegangan pintu, dan berbagai } \\
\text { mainan kayu. Kegiatan ini dapat memberikan kesempatan dan peluang kerja } \\
\text { bagi para pemuda yang terampil untuk meningkatkan kreativitasnya. }\end{array}$} \\
\hline $\begin{array}{l}\text { Kat } \\
\text { pem } \\
\text { pem } \\
\text { lim } \\
\text { berı }\end{array}$ & \\
\hline \multicolumn{2}{|r|}{$\begin{array}{l}\text { Kristiawan I. (2020) Pemberdayaan Pemuda dalam Pengelolaan Limbah Kayu } \\
\text { a Kemantren Kecamatan Jabung. Sasambo: Jurnal Abdimas (Journal of } \\
\text { 9-27. Doi: 10.36312/sasambo.v2i1.178 }\end{array}$} \\
\hline
\end{tabular}

\section{PENDAHULUAN}

Salah satu masalah utama seiring dengan majunya perkembangan dunia industri yang semakin pesat di Indonesia adalah limbah (Aisyah, 2013). Limbah merupakan sisa hasil produksi manusia yang sudah tidak bermanfaat dan tidak memiliki nilai ekonomi yang berdampak dapat mencemari lingkungan sekitar. Zulkifli (2014) menyatakan bahwa limbah merupakan zat atau bahan yang dihasilkan dari proses suatu produksi, baik industri maupun 
rumah tangga, yang keberadaannya pada kondisi tertentu tidak diinginkan oleh lingkungan karena dapat menurunkan kualitas lingkungan. Pengertian lain dari limbah yaitu sisa proses produksi; bahan yang tidak memiliki nilai atau tidak berharga untuk maksud biasa atau utama dalam pembuatan atau pemakaian; barang rusak/cacat dalam proses produksi (Kamus Besar Bahasa Indonesia, 2008).

Salah satu sumber limbah yang dapat dimanfaatkan yakni limbah hasil dari pemotongan kayu glondongan yang diambil tengahnya. Pemotongan kayu yang diambil tengahnya digunakan sebagai papan/balok, sehingga menghasilkan limbah kayu yang berupa grajen dan sadetan. Jumlah limbah yang dihasilkan dari tempat pemotongan kayu sangat banyak sekali yang menyebabkan ketidaknyamanan warga sekitar karena kayu yang tidak dipakai tersebut dibiarkan saja bahkan sampai membusuk, apalagi jika musim hujan tiba maka limbah kayu tersebut menjadi bau dikarenakan tempat tersebut becek dan berlumpur karena terlindas mobil pengangkut kayu yang membawa kayu glondongan.

Limbah yang selama ini dihasilkan dibiarkan membusuk, ditumpuk, dan dibakar. Sehingga dari keadaan tersebut berdampak negatif terhadap lingkungan. Penanggulangan terhadap limbah perlu dipikirkan, salah satu cara yang dapat dilakukan yaitu dengan memanfaatkan limbah tersebut menjadi produk yang memiliki nilai tambah dengan menggunakan teknologi terapan dengan kearifan lokal. Sehingga hasil yang diperoleh dapat dimanfaatkan oleh masyarakat.

Limbah yang diolah dapat dimanfaatkan untuk kebutuhan manusia. Akan tetapi produk yang dihasilkan juga harus memperhatikan keragaman bentuk dan kreativitas desainnya, sehingga manusia akan lebih tertarik untuk memanfaatkan produk yang dihasilkan dari limbah tersebut. Akibat dari perkembangan pendidikan serta peningkatan intensitas interaksi sosial budaya antar individu maupun kelompok masyarakat, maka mereka menuntut selalu diadakannya perubahan-perubahan produk baru yang mengikuti perkembangan zaman (Sinulaga, 2008). Dengan adanya produk baru tersebut, masyarakat akan merasa terpuaskan. Bentuk-bentuk baru dari suatu produk bisa dihasilkan dari sebuah kreativitas.

Munandar (1999) berpendapat bahwa kreativitas merupakan sebuah kemampuan dalam membuat kombinasi baru berdasarkan data, informasi, atau unsur-unsur yang ada. Kreativitas adalah sesuatu yang sudah ada dimodifikasi menjadi konsep yang baru (Semiawan, 2009). Makna kreativitas ini sering dipakai dalam bidang keilmuan kesenian, baik yang menyangkut produk, orang, prosesnya, maupun lingkungan tempat orang-orang kreatif dalam mengembangkan kreativitasnya. Suatu produk dapat dinilai kreatif jika: 1) produk bersifat baru, unik, bermanfaat atau bernilai ketika dilihat dari sudut pandang kebutuhan tertentu; 2) lebih bersifat heuristik, yaitu menyajikan sebuah cara/metode yang belum pernah dilakukan sebelumnya. Hasil dari kreatifitas yaitu sebuah desain atau gambar kerja. Desain ini menggambarkan produk yang akan dirancang, sehingga akan menghasilkan sebuah karya baru dan kreatif. Membuat sebuah kombinasi baru, kebermanfaatan, dan mengelaborasi suatu ide merupakan sebuah kemampuan kreativitas (Munandar, 1999).

Berdasarkan hasil observasi dan wawancara warga sekitar di wilayah Desa Kemantren Kecamatan Jabung terdapat 4 tempat produksi pengolahan pemotongan kayu glondongan. Setiap harinya tempat produksi pemotongan kayu ini menghasilkan lebih dari 2 truk setiap harinya jika diangkut menggunakan truk. Limbah-limbah hasil pemotongan kayu tersebut berupa, grajen, akar kayu, sadetan, kulit kayu, serpihan potongan kayu yang tidak terpakai yang kadang warga sekitar yang dekat dimanfaatkan untuk kayu bakar rumah dan kadang juga digunakan untuk bakar-bakar ketika berada di pos kamling.

Hasil observasi dan wawancara di Desa Kemantren berkenaan dengan para pemuda/pemudi, didapati informasi bahwa 20 pemuda dan pemudi yang usianya produktif yang belum bekerja karena disebabkan setelah lulus sekolah menengah pertama tidak melanjutkan ke jenjang atasnya. Mereka kebanyakan memilih untuk bekerja sebagai buruh 
harian, buruh lepas, dan pembantu rumah tangga di perumahan dekat desa dan di wilayah kompleks militer.

Melihat dari kondisi tersebut perlu dilakukan sebuah terobosan yang mampu merubah kondisi tersebut. Pemanfaatan limbah kayu menjadi hasil karya seni yang nantinya mampu menambah pendapatan pemuda dan mengurangi limbah kayu yang dihasilkan oleh tempat produksi pemotongan kayu. Hasil karya seni yang terbuat dari limbah kayu dapat berupa lampu hias, souvenir gantungan kunci, hiasan dinding, rak buku, rak sepatu, tempat ATK dan lain-lain. Pemanfaatan limbah kayu ini diharapkan dapat menambah pendapatan para pemuda yang bekerja sebagai buruh tidak tetap dan diharapkan mampu membuka lapangan kerja sendiri dengan mengubah limbah kayu tersebut menjadi karya seni yang memeiliki nilai ekonomis.

Tim pengabdi telah melakukan diskusi dengan mitra Hipenidha, hasilnya telah disepakati bersama bahwa yang menjadi permasalahan utama di lingkungan mitra yaitu: 1) Terdapat 4 pengusaha kayu yang limbahnya dibuang begitu saja; 2) Kurangnya kesadaran warga sekitar tentang pentingnya pengelolaan limbah kayu; 3) Limbah kayu hasil produksi pengusaha kayu gergaji yang terbuang begitu saja; 4) Terdapat banyak para pemuda yang masih produktif tetapi tidak memiliki lapangan kerja (bekerja sebagai buruh harian lepas); dan 5) Belum adanya pengetahuan mengenai pemanfaatan limbah kayu menjadi barang yang bernilai ekonomis.

Oleh karena itu tim pengabdi bersama dengan para pemuda di Desa Kemantren Kecamatan Jabung Kabupaten Malang melakukan kesepakatan untuk menangani permasalahan tersebut dengan mengolah limbah kayu supaya dapat di manfaatkan menjadi barang yang bernilai ekonomis. Tujuan kegiatan ini yaitu memberikan manfaat dan nilai tambah untuk para pemuda/pemudi (masyarakat) dalam melihat kondisi lingkungan sekitarnya, yaitu limbah kayu yang bisa diolah kembali dan menjadi karya seni sederhana serta mempunyai nilai ekonomis.

\section{METODE PELAKSANAAN}

Pelaksanaan program Hipenidha ini menggunakan metode pendekatan kultural. Pendekatan kultural yaitu pendekatan yang digunakan untuk ketercapaian suatu program dalam membantu permasalahan mitra. Beberapa pendekatan yang dilakukan di wilayah mitra, yaitu: 1) Sosialiasi, yaitu kegiatan yang dilakukan dalam pendekatan ini dengan menyampaikan tujuan program dan kegiatan yang akan disediakan kepada para pemuda berkenaan pengelolaan limbah kayu yang tidak bernilai menjadi limbah yang bernilai ekonomis; 2) Partisipasi, yaitu keterlibatan para pemuda secara aktif pada setiap kegiatan yang dilakukan, termasuk kemungkinan menjadi penyedia alat produksi yang dapat digunakan sebagai penambah jika ada keterbatasan media alat produksi seperti gergaji, mesin bor, dll; dan 3) Silaturahmi, yaitu menjalin keakraban dengan para pemuda dan tokoh masyarakat.

Beberapa rencana kegiatan pelaksanaan program Hipenidha "Pemberdayaan Pemuda dalam Pengelolaan Limbah Kayu“, yaitu: 1) Sosialisasi pentingnya peran pemuda dalam menciptakan lapangan kerja sendiri; 2) Pendampingan pembentukan kelompok pemuda dalam pembuatan hasil olahan dari limbah kayu; 3) Pengadaan kelengkapan inventaris alat produksi limbah kayu; dan 4) Monitoring keberlangsungan kegiatan pemuda mengelola limbah kayu.

Tahapan pelaksanaan yang akan dilakukan untuk mewujudkan program Hipenidha bagi pemuda di desa Kemantren Kecamatan Jabung Kabupaten Malang, yaitu sebagai berikut: 


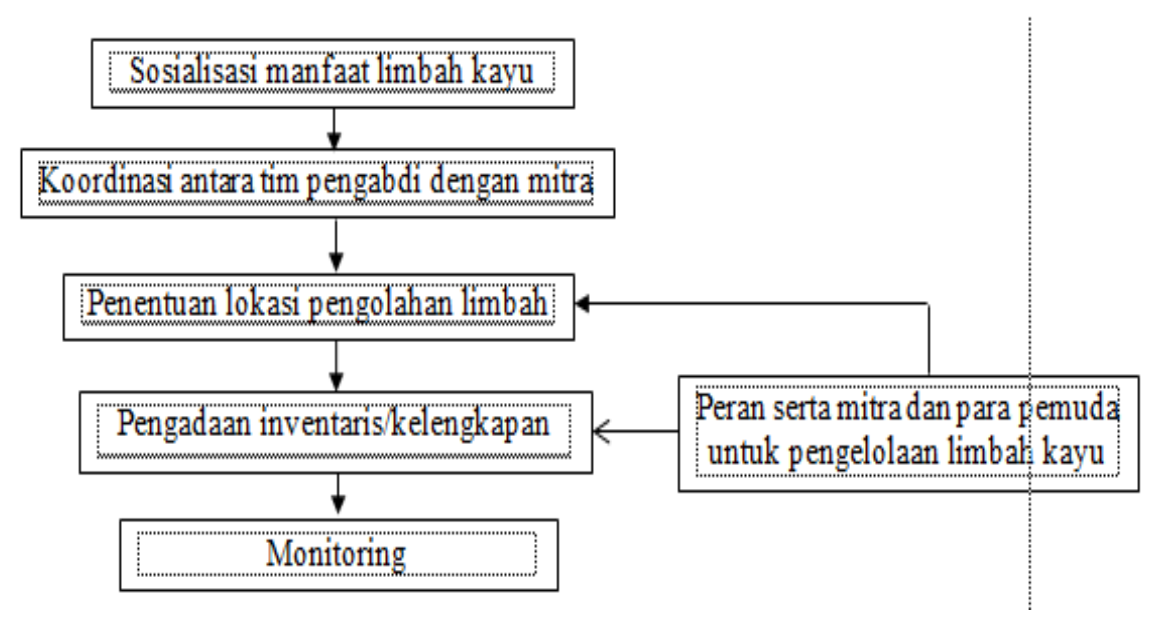

Gambar 1. Prosedur Pelaksanaan

Pendampingan dan pelatihan dari para tenaga ahli di bidang seni keterampilan dan permeubelan dilakukan untuk membantu memecahkan permasalahan yang dihadapi mitra. Para ahli di bidang seni keterampilan dan permeubelan tersebut akan memberikan pendampingan dalam proses pengolahan limbah kayu menjadi barang yang berharga dan bermanfaat.

\section{HASIL DAN PEMBAHASAN}

Tahapan pelaksanaan mesing-masing kegiatan program Hipenidha Pemberdayaan Pemuda dalam Pengelolaan Limbah Kayu Bernilai Ekonomis di Desa Kemantren Kecamatan Jabung, dapat dipaparkan sebagai berikut:

1. Sosialisasi pentingnya peran pemuda dalam menciptakan lapangan kerja sendiri

Pada tahapan ini dijelaskan tentang program Hipenidha kaitannya dengan desain dan cara pengerjaan pengolahan limbah kayu menjadi karya seni sederhana yang diberikan oleh tim kepada Mitra kerja agar dapat dengan mudah memahami sekaligus mempraktekkannya. Komponen-komponen dan ukuran-ukuran komponen dijelaskan langsung disertai dengan teknik pengerjaan yang sederhana dari limbah kayu. Kemudian diadakan diskusi antar anggota tim berdasarkan kondisi dan permasalahan mitra yang berkaitan dengan teknologi yang akan diterapkan, meliputi: material yang dipakai (bahan limbah kayu), ukuran-ukuran komponen yang digunakan, peralatan yang dibutuhkan, dan sistem kerja yang diterapkan.

\section{Hasil observasi awal yang}

dilakukan pada mitra yaitu di wilayah Desa Kemantren Kecamatan Jabung yang berkenaan dengan para pemuda, didapati informasi bahwa 20 pemuda yang usianya produktif yang belum bekerja karena disebabkan setelah lulus sekolah menengah pertama tidak melanjutkan ke jenjang atasnya. Mereka kebanyakan memilih untuk bekerja sebagai buruh harian, buruh lepas, dan sebagai pembantu rumah tangga di perumahan dekat desa dan di wilayah kompleks militer.

Melihat dari kondisi tersebut perlu dilakukan sebuah trobosan yang mampu merubah kondisi tersebut. Pemanfaatan limbah kayu menjadi hasil karya seni yang nantinya mampu menambah pendapatan pemuda dan mengurangi limbah kayu yang dihasilkan oleh tempat produksi pemotongan kayu. Hasil karya seni yang terbuat dari limbah kayu dapat berupa hiasan dinding, frame foto, tempat ATK, rak buku, pegangan pintu, dan berbagai mainan kayu. Pemanfaatan limbah kayu ini diharapkan dapat menambah pendapatan para pemuda yang bekerja sebagai buruh tidak tetap dan diharapkan mampu membuka lapangan kerja sendiri dengan mengubah limbah kayu tersebut menjadi karya seni yang memiliki nilai 
ekonomis.

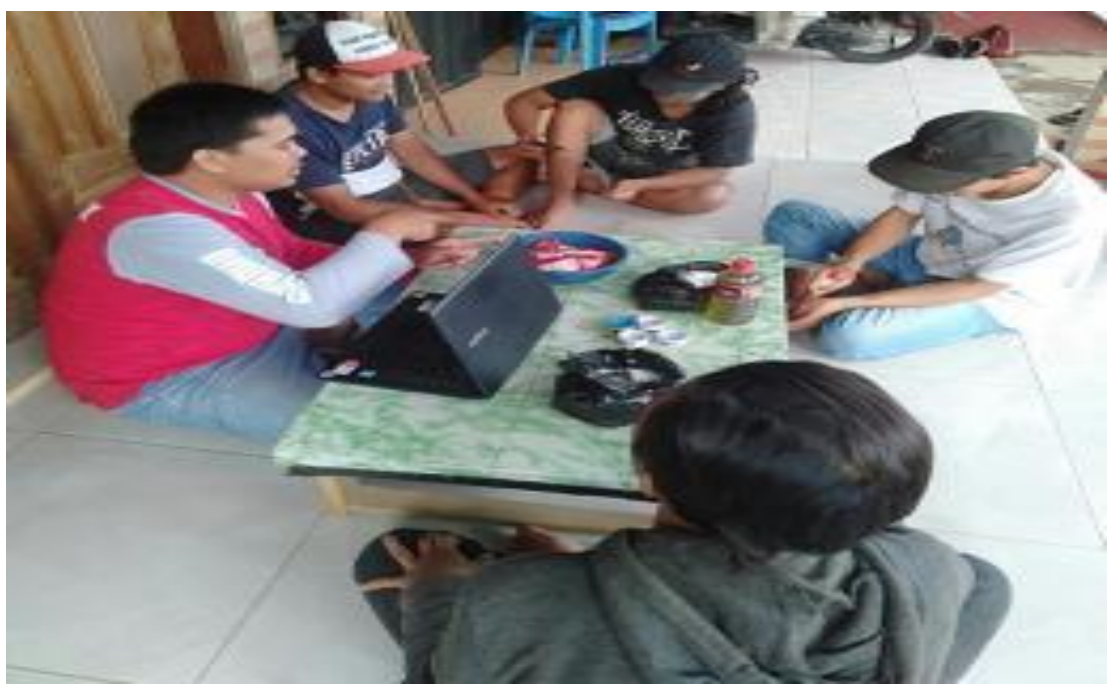

Gambar 2. Kegiatan Sosialisasi

Modal keterampilan yang dimiliki oleh para pemuda Desa Kemantren perlu sekiranya melakukan sosialisasi program kerja yang diawali dengan kunjungan ke Desa Kemantren (mitra) dan memberikan pengertian maksud dan tujuan kegiatan tersebut kepada Ketua RT dan warga di sekitar lokasi mitra. Kegiatan yang dilakukan oleh tim untuk memberikan manfaat dan nilai tambah untuk para pemuda/pemudi (masyarakat) dalam melihat kondisi lingkungan sekitarnya untuk diolah kembali (kreativitas), seperti halnya limbah-limbah kayu dan sejenisnya yang bisa diolah kembali dan menjadi karya seni sederhana serta mempunyai nilai ekonomis.

3. Pendampingan pembentukan kelompok pemuda dalam pembuatan hasil olahan dari limbah kayu

Persiapan kegiatan program Hipenidha Pemberdayaan Pemuda dalam Pengelolaan Limbah Kayu Bernilai Ekonomis di Desa Kemantren Kecamatan Jabung dilakukan dengan sebaik-baiknya. Penyusunan jadwal kegiatan (shedulle) yang ada kaitannnya dengan inovasi dan kreativitas disain karya seni sederhana melalui pendampingan oleh tim dan para ahli di bidangnya.
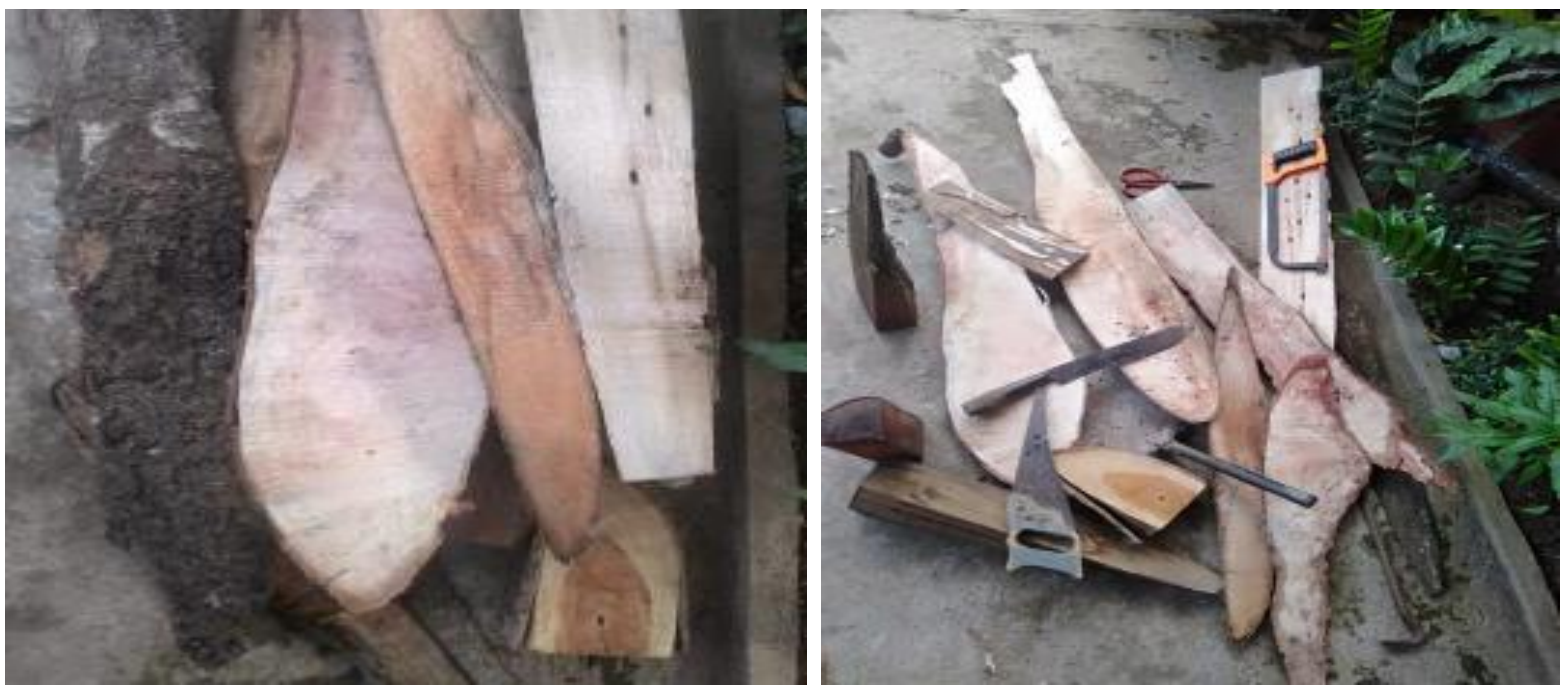

Gambar 3. Limbah Kayu dan Peralatan yang Digunakan 

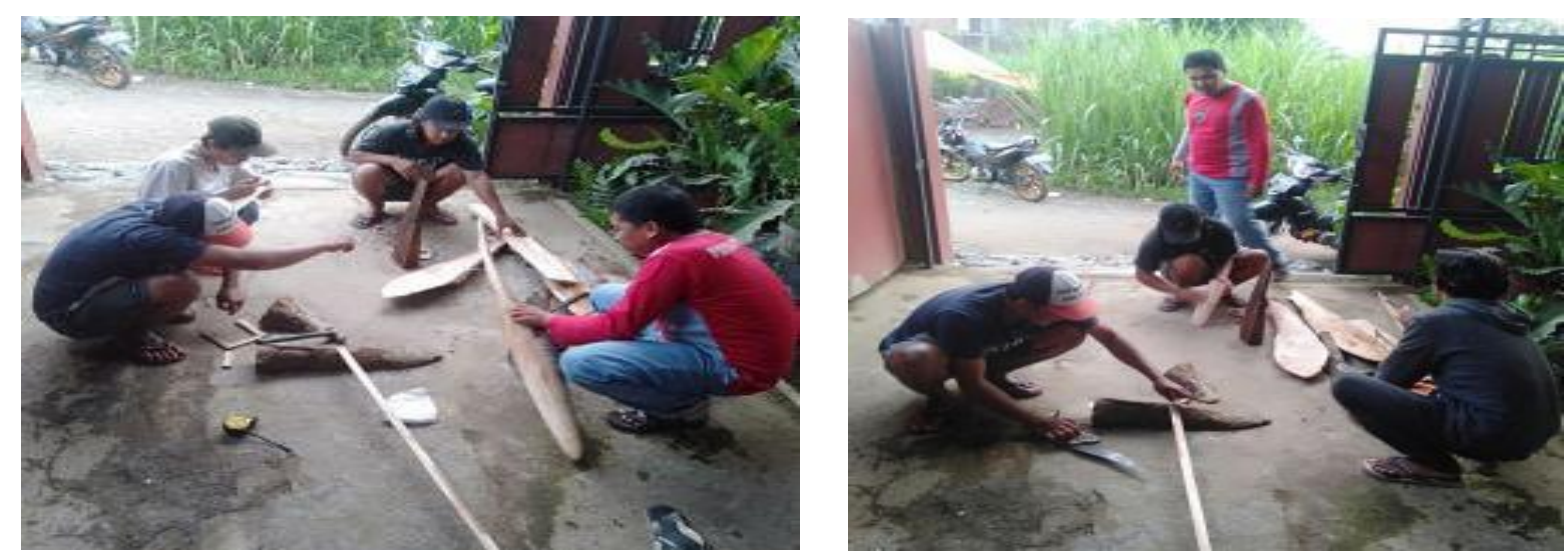

Gambar 4. Pendampingan Kepada para Pemuda
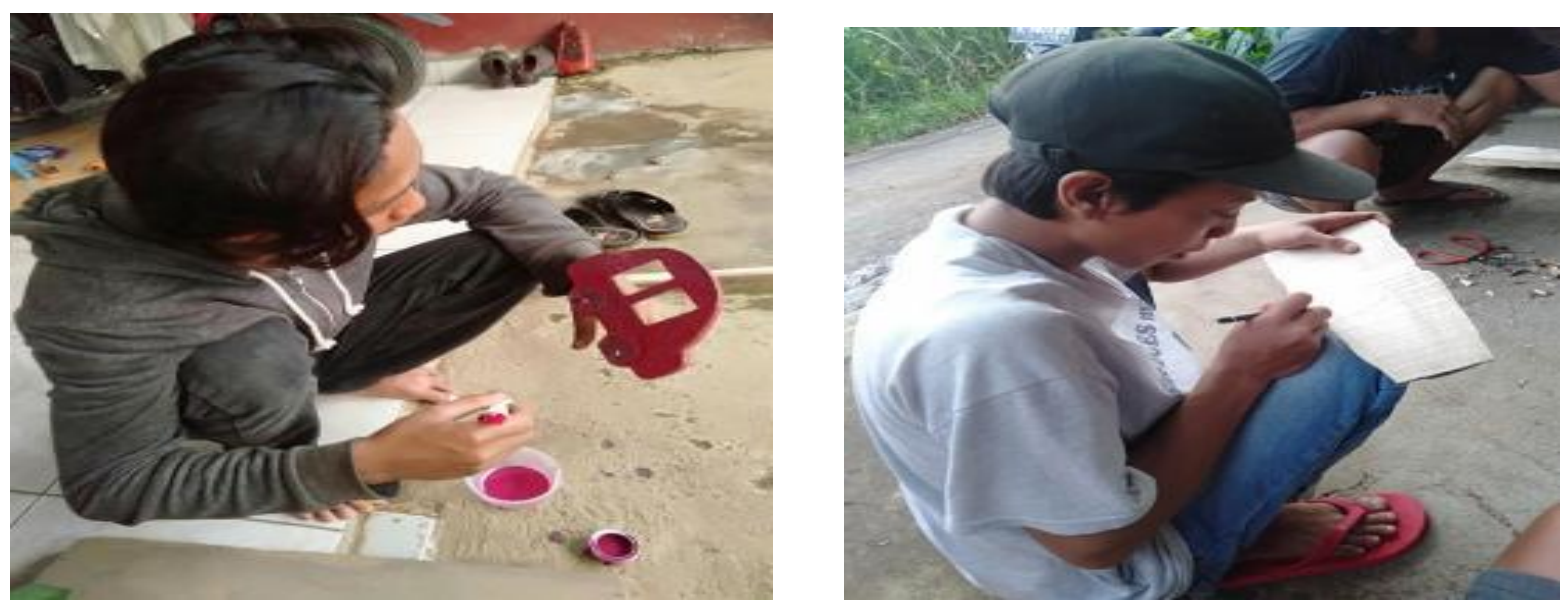

Gambar 5. Proses Pembuatan Karya Seni Sederhana

Pada tahapan ini yaitu membuat rancangan kegiatan tim dengan menggunakan metode pendampingan kepada mitra melalui tahapan yaitu:

a. Inovasi dan kreativitas desain, pada tahapan ini yaituisepemperlihatkan contohcontoh sekitar lingkungan kita.

b. Motivasi kewirausahaan (bernilai ekonomis), pada tahapan ini memberikan pengarahan langkah-langkah/motivasi membangun suatu usaha yang sekiranya nanti ada pemuda yang mempunyai usaha atau mengembangkan usaha dari orang tuanya.

4. Monitoring keberlangsungan kegiatan pemuda mengelola limbah kayu

Kegiatan monitoring dilakukan setelah proses pendampingan selesai. Monitoring terhadap pelaksanaan kegiatan program Hipenidha Pemberdayaan Pemuda dalam Pengelolaan Limbah Kayu Bernilai Ekonomis di Desa Kemantren Kecamatan Jabung dapat diperoleh beberapa hasil di antaranya, yaitu:

a. Informasi tentang pemanfaatan limbah yang diberikan mudah dipahami oleh mitra (pemuda Desa Kemantren). Hal ini terlihat dari banyaknya pertanyaan yang berlanjut pada diskusi yang dilakukan selama proses kegiatan berlangsung;

b. Peningkatan kreativitas dan pengetahuan mitra dalam membuat karya seni sederhana yang terbuat dari bahan limbah kayu;

c. Antusiasme para pemuda di Desa Kemantren dalam mengikuti kegiatan, dilihat dari persentase kehadiran selama mengikuti pendampingan dan praktek membuat karya seni sederhana dari pengolahan limbah kayu; 
d. Peserta dapat mengadopsi teknologi yang diberikan selama program Hipenidha.

Partisipasi mitra (pemuda Desa Kemantren) dalam pelaksanaan program ini sesuai dengan yang diharapkan mitra:

1. Berperan aktif meluangkan waktunya untuk mengikuti semua kegiatan yang telah dijadwalkan. Sehingga, dapat mengetahui dan mempraktekkan langsung metode pembuatan pengolahan limbah kayu menjadi karya seni sederhana yang telah diberikan.

2. Bersedia menyiapkan atau menyediakan tempat kegiatan praktek atau pembuatan karya seni sederhana dari pengolahan limbah kayu.

Pelaksanaan program Hipenidha Pemberdayaan Pemuda dalam Pengelolaan Limbah Kayu Bernilai Ekonomis dengan Pemuda di Desa Kemantren Kecamatan Jabung sebagai mitra melakukan kegiatan praktek dengan menghasilkan beberapa karya seni sederhana dari limbah kayu yaitu: lampu hias, gantungan kunci, hiasan dinding, frame foto, tempat ATK.
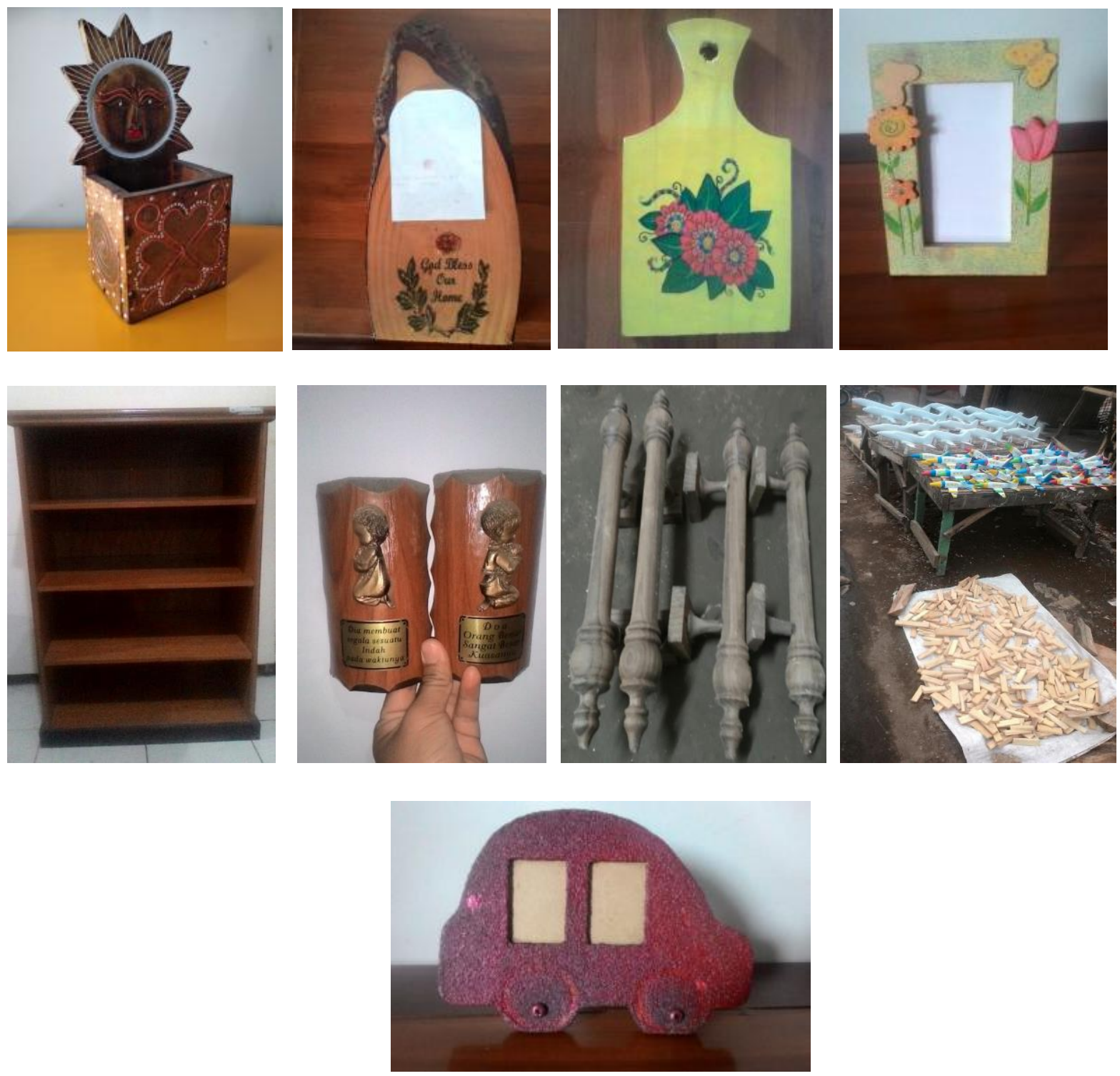

Gambar 6. Produk Karya Seni Sederhana dari Limbah Kayu

Dalam proses pengerjaannya (praktek) mitra dibagi dalam tiga kelompok dengan dua desain yang berbeda. Langkah-langkah pengerjaannya sebagai berikut:

1) Memperkenalkan alat-alat sederhana pertukangan dan cara menggunakannya pada benda yang dipraktekkan secara benar dan penuh konsentrasi, karena hal ini menyangkut 
keselamatan kerja;

2) Mengukur sesuai desain, pada tahapan ini yaitu cara membuat ukuran sesuai pesanan atau gambar;

3) Membuat sambungan dan melubang, pada bagian ini yaitu cara membuat sambungan kayu sederhana dan cara melubangnya dengan menggunakan alat yang sederhana.

4) Merakit, pada tahapan ini yaitu merakit semua sambungan yang telah dibuat, sehingga membentuk sebuah perabot sesuai dengan gambar;

5) Finishing, pada bagian ini hasil kerajinan yang telah selesai dirakit didempul, kemudian dihaluskan dengan menggunakan amplas. Setelah semua permukaan halus dilanjutkan dengan pengecatan dan plitur.

Begitu banyak macam seni kerajinan yang dapat dibuat dari limbah kayu. Pengrajin dan pengembang seni kerajinan harus terus menuangkan inovasi dan kreativitasnya dalam sebuah produk agar nantinya eksistensinya terus menyesuaikan seiring dengan perkembangan zaman. Adanya limbah merupakan hal yang wajar dalam kehidupan ini, akan tetapi ide kreatif serta kemauan yang kuat untuk mendaur ulang limbah-limbah tersebut menjadi benda yang berharga diharapkan dapat dimiliki oleh setiap masyarakat. Hal ini menjadi salah satu upaya dalam menanggulangi polusi lingkungan. Seperti yang telah banyak dilakukan bahwa limbah kayu palet dapat dimanfaatkan untuk menciptakan hiasan terarium (Priambada, 2017). Selain itu limbah kayu juga dapat dimanfaatkan untuk lampu hias atau lampu dinding dengan limbah kayu yang digunakan antara lain kayu jati, sonokeling, nangka, dan akasia (Susanto, 2017).

Limbah kayu dapat dibentuk menjadi sebuah produk yang mempunyai nilai seni yang tinggi, oleh sebab itu diperlukan kreativitas tinggi dalam pengolahannya. Beberapa hasil lain dari olahan limbah kayu dapat berupa, furniture terdiri atas: meja makan, almari, dan sofa/kursi, serta art work berupa: hiasan dinding, lampu hias, serta pernak pernik lainnya (Sutarman, 2016). Selain dapat mengurangi pencemaran lingkungan yang dihasilkan dari limbah kayu, penciptaan produk karya seni dari limbah kayu ini juga dapat berfungsi untuk menaikkan nilai pakai dan nilai ekonomi suatu benda. Limbah kayu yang biasanya hanya dibakar menjadi lebih bermanfaat setelah dijadikan kerajinan seni.

Secara ekonomi pemanfaatan limbah kayu menjadi kerajinan seni dapat meningkatkan nilai jual limbah tersebut. Sehingga jika cara pengolahan limbah kayu ini dapat diberdayakan di masyarakat, dapat juga menaikkan taraf hidup masyarakat dengan menciptakan lahan pekerjaan baru dari pengolahan limbah kayu tersebut (Sutarman, 2016). Berdasarkan analisis kebutuhan dan potensi pada tahun 2004 pemanfaatan limbah potongan kayu yang jumlahnya cukup banyak menjadi produk yang bernilai ekonomi (Karsidi, 2007). Sehingga selain limbah kayu dapat dijadikan sebagai produk kerajinan seni yang bermanfaat untuk kebutuhan manusia, limbah tersebut juga dapat bernilai ekonomis di masyarakat.

\section{KESIMPULAN}

Program ini dapat memberikan dampak positif pada mitra, terutama para pemuda yang mendapatkan bekal pengetahuan dan pengalaman dalam memanfaatkan limbah yang terdapat di sekitar lingkungan, terutama untuk limbah kayu untuk pembuatan karya seni sederhana yang bernilai ekonomis. Program Hipenidha, akan dapat memberikan kesempatan dan peluang kerja bagi para pemuda yang terampil untuk meningkatkan kreativitasnya apabila mereka sudah berbaur dengan masyarakat.

\section{SARAN}

Menjaga dan melestarikan lingkungan perlu adanya sebuah solusi yang baik. Salah satunya yaitu dengan mengurangi limbah, khususnya limbah kayu yang banyak ditemukan di lingkungan masyaraat. Oleh sebab itu, diperlukan agar menjadikan limbah-limbah tersebut menjadi lebih bermanfaat dan dapat menambah nilai jual bagi masyarakat sekitar dengan 
menuangkan inovasi dan kreativitasnya sesuai dengan perkembangan zaman. Untuk menciptakan karya seni kerajinan yang kreatif diperlukan peralatan yang lengkap dan tempat yang berstandar, sehingga memudahkan dalam melaksanakan praktisi pembuatan karya kerajinan kayu.

\section{UCAPAN TERIMA KASIH}

Ucapan terima kasih kepada Universitas Wisnuwardhana Malang yang telah memberikan biaya selama kegiatan ini berlangsung.

\section{DAFTAR PUSTAKA}

Aisyah. (2013). Karakterisasi Gelas Limbah Hasil Vitrifikasi Limbah Cair Tingkat Tinggi. Jurnal Teknologi Pengelolaan Limbah, $16 \quad$ (1), 13-22. http://jurnal.batan.go.id/index.php/jtpl/article/view/1205

Depdiknas. (2008). Kamus Besar Bahasa Indonesia. Jakarta: Gramedia.

Karsidi, R. (2007). Pemberdayaan Masyarakat untuk Usaha Kecil dan Mikro. Jurnal Penyuluhan, 3(2), 136-145. https://doi.org/10.25015/penyuluhan.v3i2.2161

Munandar, U. (1999). Pengembangan Kreativitas Anak Berbakat. Jakarta: Depdiknas dan Rineka Cipta.

Priambada, K. D. B. (2017). Pemanfaatan Limbah Kayu Palet dalam Penciptaan Hiasan Terarium. Journal e-Craft, 6(5), 435-447. http://journal.student.uny.ac.id/ojs/index.php/ecraft/article/view/7268

Semiawan, C. R. (2009). Kreativitas dan Keberbakatan. Jakarta: PT. Indeks.

Sinulangga, S. (2008). Pengantar Teknik Industri. Jakarta: Graha Ilmu.

Susanto, H. (2017). Pemanfaatan Limbah Kayu sebagai Bahan Penciptaan Jam Lampu Dinding dengan Motif Hias Klasik Jawa dan Bali. Journal e-Craft, 6(6), 547-554. http://journal.student.uny.ac.id/ojs/index.php/ecraft/article/view/7558

Sutarman, I. W. (2016). Pemanfaatan Limbah Industri Pengolahan Kayu di Kota Denpasar (Studi Kasus pada CV Aditya). Jurnal PASTI, 10(1), 15-22. http://publikasi.mercubuana.ac.id/index.php/pasti/article/view/668

Zulkifli, A. (2014). Pengolaan Limbah Berkelanjutan. Yogyakarta: Graha Ilmu. 